\title{
Identification key to nymphal and adult mealybugs (Hemiptera: Pseudococcidae) associated with dragon fruits in Indonesia
}

\author{
MILA SERI REZEKI ${ }^{1,2, \vartheta}$, IDHAM SAKTI HARAHAP ${ }^{3}$, DEWI SARTIAMI ${ }^{3, v \vee}$, IRMANSYAH $^{4}$, \\ GILLIAN W. WATSON ${ }^{5}$ \\ ${ }^{1}$ Entomology Program, Graduate School, Institut Pertanian Bogor. Jl. Kamper Wing 7 Level 5, Kampus IPB Darmaga, Bogor 16680, West Java, \\ Indonesia. Tel.: +62-251-8629364, Fax.: +62-251-8629362, "email: milaserirezeki@apps.ipb.ac.id \\ ${ }^{2}$ Soekarno Hatta Agricultural Quarantine Agency, Ministry of Agriculture. Jl. Pajang, Benda, Tangerang 15126, Banten, Indonesia \\ ${ }^{3}$ Department of Plant Protection, Faculty of Agriculture, Institut Pertanian Bogor. Jl. Meranti, Kampus IPB Darmaga, Bogor 16680, West Java, \\ Indonesia. Tel.: +62-251-8629354, Fax.: +62-251-8629352, "vemail: dsartiami@ apps.ipb.ac.id \\ ${ }^{4}$ Department of Physics, Faculty of Natural Sciences and Mathematics, Institut Pertanian Bogor. Jl. Agatis, Kampus IPB Darmaga, Bogor 16680, West \\ Java, Indonesia \\ ${ }^{5}$ Department of Life Sciences, the Natural History Museum. Cromwell Rd, South Kensington, London, United Kingdom
}

Manuscript received: 19 May 2021. Revision accepted: 7 July 2021.

\begin{abstract}
Rezeki MS, Harahap IS, Sartiami D, Irmansyah, Watson GW. 2021. Identification key to nymphal and adult mealybugs (Hemiptera: Pseudococcidae) associated with dragon fruits in Indonesia. Biodiversitas 22: 3113-3118. Dragon fruit (Hylocereus spp.), belonging to Cactaceae family, is one of the horticultural commodities being developed in Indonesia for export. Phytosanitary regulations require that fruits for export must be free from diseases and pests, including mealybugs (Hemiptera: Pseudococcidae). Mealybug species commonly found on dragon fruits in Indonesia are Ferrisia virgata (Cockerell), Phenacoccus solenopsis Tinsley, Planococcus minor (Maskell) and Pseudococcus jackbeardsleyi Gimpel \& Miller. Species-level identification of these insects in the nymphal phase is difficult due to the limited number of identification keys available, so it has been necessary to create an identification key to nymphs of mealybug species found on dragon fruit. A dichotomous identification key was constructed based on microscopic morphological characteristics of the cuticle. Thus, the four species can be differentiated based on general and unique characteristics of each species in the nymphal and adult stages. The diagnostic features that can be used to separate the four species in the nymphal phase are the presence or absence of: discoidal pores around the eyes; anal lobe bars; tubular ducts on the dorsum; and a denticle on each tarsal claw.
\end{abstract}

Keywords: Ferrisia virgata, morphology, Phenacoccus solenopsis, Planococcus minor, Pseudococcus jackbeardsleyi

\section{INTRODUCTION}

The export of dragon fruits (Hylocereus spp.), a member of the family Cactaceae, has increased to support the Indonesian agricultural export industry. In 2019 there was $91.600 \mathrm{~kg}$ of dragon fruits being exported (BPS 2020). Fruits for export must be inspected to ensure they are free of diseases and pests to satisfy the phytosanitary requirements for fruit export. Mealybugs are some of the pests found on dragon fruit, so it is crucial to be able to detect and identify them on this export commodity.

Mealybugs occur on dragon fruit skin individually or in aggregations. Damage symptoms caused by these pests are a dry skin surface, fruit shrinkage, wrinkled skin, and honeydew which causes sooty molds (Mani and Shivaraju 2014; Nurhafizhah et al. 2020). According to Sartiami et al. (2019), the mealybug species found on dragon fruits in Indonesia are Ferrisia virgata (Cockerell), Phenacoccus solenopsis Tinsley, Planococcus minor (Maskell), and Pseudococcus jackbeardsleyi Gimpel \& Miller, which belong to the family Pseudococcidae, order Hemiptera. In addition to dragon fruit, all these four mealybug species have a wide range of host plants. For example, according to Morales et al. (2021), the host-plant range of $F$. virgata includes 79 families and 213 genera; that of $\mathrm{Pl}$. minor includes 73 families and 206 genera; the host range of $P h$. solenopsis covers 63 plant families and 209 genera, and that of Ps. jackbeardsleyi consists of 52 families and 112 genera.

In Indonesia, the common species of Ferrisia is $F$. virgata, but it has been revised to include 18 species based on morphological and molecular data (Kaydan and Gullan 2012). However, Zarkani et al. (2020) reported that another species, F. dasylirii (Cockerell) was found in Bengkulu, Indonesia, and a prior report by Sartiami et al. (2016a) stated that the presence of $F$. dasylirii had been recorded in the neighboring country, Malaysia. $F$. virgata causes damage to cotton in Brazil and the second-instar nymphs spread almost to all parts of the plant (Oliveira et al. 2014).

Planococcus minor was found in Indonesia in 1956 on Acalypha indica (Sartiami et al. 2016b), but Ps. jackbeardsleyi was reported in Indonesia in 1973 and is a polyphagous insect that causes damage to vegetables, fruits, and ornamental plants (Muniappan et al. 2011; Wang et al. 2018), whereas $P h$. solenopsis is known to have been present in Indonesia since 2007 (ICAC 2011). Phenacoccus solenopsis caused damage to tomato plants in Egypt and the cotton industry in Australia (Ibrahim et al. 2015; Wilson et al. 2018). 
The four species of mealybugs associated with dragon fruit need to be detected and identified before export. Detection involves searching for the presence of the mealybugs on fruit surfaces. Detection can be carried out based on morphological characters or molecular techniques (Pacheco da Silva et al. 2014). Molecular techniques are considered if morphological identification cannot be run due to insect damage, resulting in the loss of diagnostic morphological features (Bahder et al. 2015) or if the insect is immature. The four species can be differentiated based on the general and unique characteristics of the adult female of each species. Generally, identification of mealybug species is based on the adult female stage because they are long-lived, relatively conspicuous, and numerous identification keys are available to separate genera and species (Williams and Granara de Willink 1992; Gullan 2000; Williams 2004). The identification of the nymphal stage is rarely done due to the limited number of identification keys available. It is, therefore, necessary to provide an identification key to nymphal stages of these mealybugs, to enable rapid diagnosis of nymphal mealybugs found on dragon fruit at pre-export inspection. This study provides an identification key to separate the female nymphal stages and adult of four mealybug species associated with dragon fruit in Indonesia.

\section{MATERIALS AND METHODS}

\section{Procedures}

Preparation and rearing of test insects

Four species of mealybugs, F. virgata, Pl. minor, Ph. solenopsis and Ps. jackbeardsleyi were collected from dragon fruits in the Bogor and Tangerang regions of Java, Indonesia. The identification of the test insects was carried out using the keys in the book Mealybugs of Southern Asia (Williams 2004), Mealybugs of Central and South America (Williams and Granara de Willink 1992), and Cox (1989). The mealybugs were reared according to each alternative hosts: F. virgata was reared on Psidium guajava seedlings, $P l$. minor was reared on chayote (Sechium edule), Ph. solenopsis was reared on tomato plants (Solanum lycopersicum), and Ps. jackbeardsleyi was reared on bottle gourds (Lagenaria sp.).

Female nymphs and adults obtained from the field were gently placed on each appropriate host plant. For $F$. virgata and $\mathrm{Ph}$. solenopsis, the host plants were put in an individual cage of $100 \times 40 \times 120 \mathrm{~cm}$ outdoors. The other mealybug species were reared in plastic containers covered with dark cloth in the laboratory at a temperature of $27^{\circ} \mathrm{C}$ and relative humidity of $50-60 \%$.

\section{Microscope slide preparation}

Semi-permanent slide mounts of nymphal and adult female cuticles were prepared using a methodology modified from Walker (1988), Watson and Chandler (2000), Krantz and Walter (2009), and Sirisena et al. (2013). Mealybugs were put into Syracuse dishes, each containing 6-8 $\mathrm{ml}$ of Essig's fluid and 1-2 drops of chloroform. Each insect was punctured on the dorsum of the metathorax, and then 1 or 2 drops of acid fuchsin stain were added. The dishes were heated to $60-70{ }^{\circ} \mathrm{C}$ for $10-15$ minutes and then cooled. The body contents of each mealybug were expelled by gently pressing the body with a brush; then, the mealybugs were transferred to another Syracuse dish containing Essig's fluid and chloroform. The body contents were again expelled until the cuticle was thoroughly clean and looking transparent. The specimens were then transferred to an object-glass containing drops of Heinz mounting medium, then covered with a glass coverslip and dried at $60^{\circ} \mathrm{C}$ for 5 minutes. Ten slide mounts were made of each of the nymphal and adult stages of each species.

\section{The making of the identification key}

The identification key is based on the morphological characteristics of each nymphal and adult female stage of each mealybug species. Morphological observations were carried out under a compound microscope (Nikon Eclipse 80i). Identification of the adult female stages was made using the keys in, Cox (1989), Williams and Granara de Willink (1992) and Williams (2004). A dichotomous identification key was prepared and illustrated with photomicrographs to show the unique character of the adult female and nymphal stages of each species.

\section{RESULTS AND DISCUSSION}

\section{Morphological characterization of nymphal stages of Ferrisia virgata}

The nymphal and adult stages of $F$. virgata each have 1 pair of cerarii on the anal lobes, 1 circulus, and anterior and posterior ostioles. The first-instar nymph of $F$. virgata has 6 antennal segments, with a total length of 151-166 $\mu \mathrm{m}$, and an anal ring width of 25-28 $\mu \mathrm{m}$. The ventral and dorsal surfaces have trilocular pores, with the number of trilocular pores on the dorsum being higher than the venter. Each anal lobe cerarius consists of 2 conical setae, a trilocular pore, no auxiliary setae, and situated on unsclerotized cuticle.

The antenna of second-instar females consists of 6 segments, with a total length of 207-234 $\mu \mathrm{m}$, and an anal ring width of 32-41 $\mu \mathrm{m}$. The dorsum of the head, thorax, and abdomen have enlarged, Ferrisia-type tubular ducts (see Figure 1.K), and trilocular pores; the Ferrisia-type tubular ducts are present submarginally on the head and thorax, and on the submargin and in medial areas of the abdomen. Ventral oral collar tubular ducts are present on the submargin and submedial parts of the head, thorax, and abdomen, and trilocular pores are scattered throughout the body. Each anal lobe cerarius contains 2 conical setae, 3 or 4 trilocular pores, a flagellate auxiliary seta, and is situated on unsclerotized cuticle.

The third-instar female has 7 antennal segments, with a length of 315-365 $\mu \mathrm{m}$, and an anal ring width of 54-63 $\mu \mathrm{m}$. Ferrisia-type tubular ducts are present on the dorsal part of the head, thorax, and abdomen. Ventral oral collar tubular ducts present on the head, thorax, and abdomen. Trilocular pores are scattered over the dorsal and ventral surfaces of 
the body. Each anal lobe cerarius with 2 conical setae, 10 20 trilocular pores, 2 or 3 auxiliary setae, and is situated on unsclerotized cuticle.

\section{Morphological characterization of nymphal stages of Phenacoccus solenopsis}

There are several common characteristics of $P h$. solenopsis present from the first-instar nymph to the adult stage: 18 pairs of cerarii, a denticle on each tarsal claw, 1 circulus, and presence of anterior and posterior ostioles. The antennal total length and number of segments for each of the nymphal and adult stages differ, as do other characteristics described below.

The first-instar nymph has 6 antennal segments, with a total length of 187-200 $\mu \mathrm{m}$, and an anal ring width of 23-29 $\mu \mathrm{m}$. Trilocular pores are present on the dorsum of the head, thorax, and abdomen, also with lanceolate setae, whereas the ventral body surface has quinquelocular pores and flagellate setae. Each anal lobe cerarius consists of 2 lanceolate setae, 1 trilocular pore and no auxiliary setae.

The second-instar female has 6 antennal segments, with a total length of 236-266 $\mu \mathrm{m}$, and an anal ring width of 38$49 \mu \mathrm{m}$. Trilocular pores are present on the dorsal and ventral surfaces of the head, thorax and abdomen. Ventral oral collar tubular ducts are present on the submargin and/or medial areas of the head, thorax, and abdomen. Each anal lobe cerarius consists of 2 lanceolate setae, 3 or 4 trilocular pores and no auxiliary setae.

The third-instar female has 7 antennal segments, with a total length of 358-391 $\mu \mathrm{m}$, and an anal ring width of 51-63 $\mu \mathrm{m}$. Trilocular pores are present on the dorsal and ventral surfaces of the body. Ventral oral collar tubular ducts are present on the margins, submargins and/or medial areas of the head, thorax and abdomen. Each anal lobe cerarius with 2 lanceolate setae, 10-15 trilocular pores and no auxiliary setae.

\section{Morphological characterization of nymphal stages of Planococcus minor}

The nymphal stages of $P l$. minor have anal lobe bars, 18 pairs of cerarii, 1 circulus, and anterior and posterior ostioles. First- and second-instar female each have 6 antennal segments, with total antennal lengths of 147-156 $\mu \mathrm{m}$ and 191-206 $\mu \mathrm{m}$, respectively, and anal ring widths of 24-28 $\mu \mathrm{m}$ and 33-41 $\mu \mathrm{m}$, respectively. The dorsal and ventral body surfaces lack tubular ducts and only have trilocular pores and flagellate setae. The anal lobe cerarius of the first-instar nymph has 2 conical setae, 1 trilocular pore, and no auxiliary setae, whereas that of the secondinstar female have 2 conical setae, 1 auxiliary seta and 3 or 4 trilocular pores. The anal lobes of both instars are sclerotized.

The third-instar female has 7 antennal segments, with a total antennal length of 271-290 $\mu \mathrm{m}$, and an anal ring width of 51-56 $\mu \mathrm{m}$. Trilocular pores are present on the dorsal and ventral body surfaces. Tubular ducts are absent. The anal lobe cerarius is situated on sclerotized cuticle and consists of 2 conical setae with 1 or 2 auxiliary setae and 8-15 trilocular pores.

\section{Morphological characterization of nymphal stages of Pseudococcus jackbeardsleyi}

All female developmental stages of $P$. jackbeardsleyi have discoidal pores in a sclerotised patch beside each eye, anterior and posterior ostioles, 1 circulus, and 17 pairs of cerarii. The first-instar nymph has 6 antennal segments, with a total length of $149-164 \mu \mathrm{m}$, and an anal ring width of 24-29 $\mu \mathrm{m}$. A discoidal pore is present beside each eye. Trilocular pores are present on the dorsal and ventral surfaces of the body. Each anal lobe cerarius with 2 conical setae, 1 trilocular pore and no auxiliary setae.

The second-instar female has 6 antennal segments, with a total length of 187-209 $\mu \mathrm{m}$, and an anal ring width of 31$37 \mu \mathrm{m}$. Each eye is associated with 1 or 2 discoidal pores. Dorsal oral rim tubular ducts are present submarginally on the head, thorax, and abdomen. Oral collar tubular ducts are absent. Each anal lobe cerarius with 2 conical setae, 1218 trilocular pores and 1 auxiliary setae.

The third-instar female has 7 antennal segments, with a total length of 313-323 $\mu \mathrm{m}$, and an anal ring width of 51-53 $\mu \mathrm{m}$. Each eye is associated with 3 discoidal pores. Dorsal oral rim tubular ducts and dorsal oral collar tubular ducts are present on the head, thorax, and abdomen. Each anal lobe cerarius with 2 conical setae, 30-40 trilocular pores and 3 auxiliary setae.

Dichotomous key to separate the nymphal and adult female mealybug species found on dragon fruit in Indonesia based on morphological features

1. Antenna with 6 segments (first-instar nymph)..............2 Antenna with 7-9 segments

2. Each eye associated with at least 1 discoidal pore (Figure 1.A); ventral oral rim tubular ducts present (Figure 1.B) or absent ...3

- Each eye not associated with any discoidal pores; ventral oral rim tubular ducts absent.

3. Each anal lobe cerarius with 1 trilocular pore and 0 auxiliary setae (Figure 1.C); oral rim tubular ducts absent; each eye associated with 1 discoidal pore .......... ....... First-instar nymph, Pseudococcus jackbeardsleyi Each anal lobe cerarius with 12-18 trilocular pores and 1 auxiliary seta (Figure 1.D); head, thorax, and abdominal submargins with oral rim tubular ducts; each eye associated with 1 or 2 discoidal pores ..... Second-instar nymph, Pseudococcus jackbeardsleyi

4. Dorsal setae lanceolate (Figure 1.E); tarsal claw with a denticle on plantar surface (Figure 1.F) .......................5 Dorsal setae flagellate; tarsal claw without a denticle...6

5. Venter with quinquelocular pores (Figure 1.G) but without oral collar tubular ducts; antennal length less than 210 $\mu \mathrm{m}$.......... First-instar nymph, Phenacoccus solenopsis Venter without quinquelocular pores but with oral collar tubular ducts (Figure 1.H); antennal length more than 230 $\mu \mathrm{m}$...... Second-instar nymph, Phenacoccus solenopsis 
6. Venter of each anal lobe with sclerotised anal lobe bar (Figure 1.I). .7

- Venter of each anal lobe without anal lobe bar. 8

7. Each anal lobe cerarius without auxiliary setae; antennal length less than $165 \mu \mathrm{m}$; anal ring less than 30 $\mu \mathrm{m}$ wide..............First-instar nymph, Planococcus minor Each anal lobe cerarius with 1 auxiliary seta (Figure 1.J); antennal length more than $185 \mu \mathrm{m}$; anal ring more than $31 \mu \mathrm{m}$ wide

Second-instar nymph, Planococcus minor

8. Each anal lobe cerarius with 1 trilocular pore and 0 auxiliary setae; without dorsal Ferrisia-type tubular ducts or ventral oral collar tubular ducts

First-instar nymph, Ferrisia virgata Each anal lobe cerarius with 3 or 4 trilocular pores and 1 auxiliary seta; dorsum of head, thorax and abdomen with Ferrisia-type tubular ducts (Figure 1.K); venter of head, and thoracic and abdominal submargins and submedial areas, with oral collar tubular ducts (Figure 1.L)

Second-instar nymph, Ferrisia virgata

9. Each eye associated with 2-9 discoidal pores on sclerotized cuticle; submargins of head, thorax, and abdomen with dorsal oral rim tubular ducts, each duct rim associated with 1 or 2 flagellate setae.... 10

- Eyes not associated with discoidal pores or sclerotized cuticle; submargins of head, thorax, and abdomen without dorsal oral rim tubular ducts ..11

10. Each eye associated with 2 or 3 discoidal pores on sclerotized cuticle; venter of posterior abdomen without vulva or multilocular pores

...... Third-instar nymph, Pseudococccus jackbeardsleyi

- Each eye associated with 4-9 discoidal pores on sclerotized cuticle; venter of posterior abdomen with both vulva and multilocular pores

Adult female, Pseudococcus jackbeardsleyi

11. Dorsum with Ferrisia-type tubular ducts (Figure 1.K) ...12

- Dorsum without Ferrisia-type tubular ducts .13

12. Venter of posterior abdomen without vulva or multilocular disc pores .... Third-instar nymph, Ferrisia virgata

- Venter of posterior abdomen with both vulva and multilocular disc pores ... Adult female, Ferrisia virgata

13. Venter of each anal lobe with a sclerotized, narrow anal lobe bar (Figure 1.L); dorsal setae flagellate ............ 14

- Venter of each anal lobe without an anal lobe bar; dorsal setae lanceolate (Figure 1.E) . .15

14. Venter of posterior abdomen without vulva or multilocular disc pores

Third-instar nymph, Planococcus minor
Venter of posterior abdomen with both vulva and multilocular disc pores ...... Adult female, Planococcus minor

15. Venter of posterior abdomen without vulva or multilocular discpores

Third-instar nymph, Phenacoccus solenopsis

- Venter of posterior abdomen with both vulva and multilocular disc pores

Adult female, Phenacoccus solenopsis

\section{Discussion}

Mealybug species are usually identified based on the observation of morphological features on slide-mounted specimens (Miller et al. 2014). Nymphal and adult mealybugs can be distinguished based on their morphological characteristics; adult females possess a vulva on the venter of the posterior abdomen is absent in the nymphal stages. Ferrisia virgata has Ferrisia-type tubular ducts on the dorsum in the adult female, secondinstar female and third-instar female stages; the first-instar lacks these ducts and has only trilocular pores. The secondinstar female and third-instar female have ventral oral collar tubular duct, but lacks dorsal oral collar tubular duct (Wakgari and Giliomee 2005). Planococcus minor has anal lobe bars in all the developmental stages. However, this species has very similar morphology to that of Planococcus citri (Risso); adult females of these species can be separated using a discriminant function based on scoring morphological characteristics, provided by Cox (1989). In $P h$. solenopsis the tarsal claws have a denticle in all the developmental stages; the first-instar nymph has quinquelocular pores on the venter, but this feature is not present in the subsequent developmental stages. The second-instar female and third-instar female have ventral oral collar tubular duct, but it is not present in the dorsum. According to Hodgson et al. (2008), the second-instar male of Ph. solenopsis has ventral and dorsal oral collar tubular duct. The third-instar of Ph. solenopsis has 7 antennal segments, but the adult female has 9 (occasionally 8) segments (Williams 2004), whereas the other species have only 8 antennal segments. Pseudococcus jackbeardsleyi has discoidal pores around the eyes in all the developmental stages and oral rim tubular ducts on the body in all stages, except the first-instar nymph.

The importance of identifying mealybugs from the firstinstar nymphs is the acceleration of agricultural quarantine services for dragon fruit exports. Mealybugs found on dragon fruit to be exported must be examined and identified based on both nymphs and adult females. This key to nymphal stages and the adult mealybugs is needed because adult females are not always collected at the time of the sampling and the period from egg to adult is relatively long, thus when nymphs are collected these must be reared to the adult stage because keys are usually found for this developmental stage. 

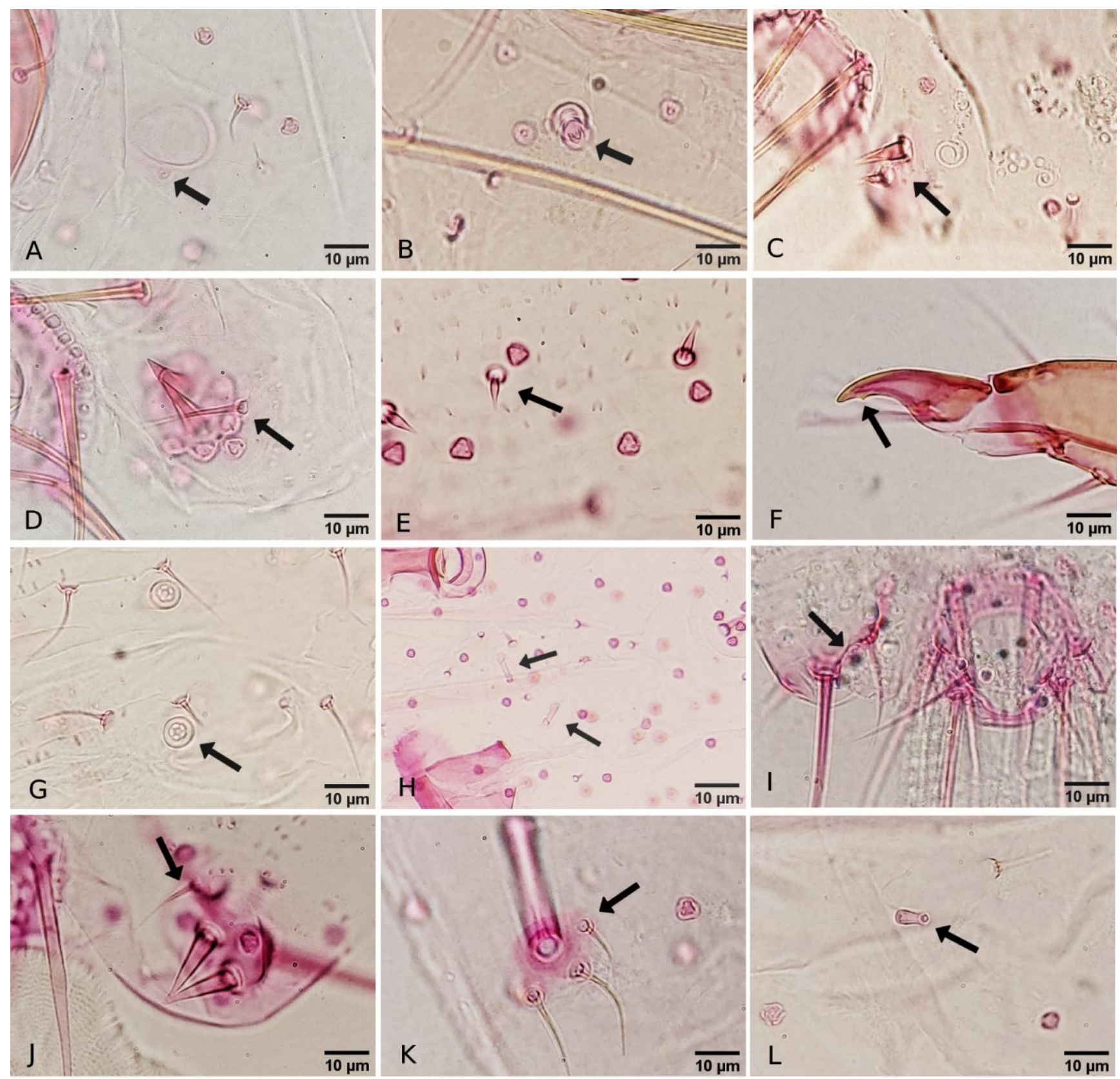

Figure 1. Morphological characterization of nympal and adult female of mealybugs species found on dragon fruit in Indonesia: A. Discoidal pore beside the eye (arrowed); B. Ventral oral rim tubular duct (arrowed); C. Anal lobe cerarius of first-instar nymph, Pseudococcus jackbeardsleyi (arrowed); D. Anal lobe cerarius of second-instar nymph, Ps. jackbeardsleyi (arrowed); E. Lanceolate setae (arrowed); F. Tarsal claw with denticle on plantar surface (arrowed); G. Quinquelocular pore (arrowed); H. Ventral oral collar tubular duct (arrowed); I. Anal lobe of first-instar nymph, Planococcus minor with anal lobe bar (arrowed); J. Anal lobe cerarius of second-instar nymph, Pl. minor with auxiliary seta (arrowed); K. Ferrisia-type tubular duct (arrowed); L. Ventral oral collar tubular duct (arrowed)

The period from oviposition to adult female for $P l$. minor is 27 days at $29^{\circ} \mathrm{C}$ in cotton (Francis et al. 2012). The development period of egg to adult females for $F$. virgata is 19.1 days at $28{ }^{\circ} \mathrm{C}$ in cotton (Oliveira et al. 2013). The period of egg development to adult females for Ph. solenopsis is 20.6 days at $27^{\circ} \mathrm{C}$ (Prasad et al. 2012). The female nymphal period of Ps. jackbeardsleyi is 18 to 21 days and nymphs can develop well at $35{ }^{\circ} \mathrm{C}$ compared to $25{ }^{\circ} \mathrm{C}$ (Mani and Shivaraju 2014; Piyaphongkul et al. 2018).

In conclusion, all the developmental stages of the female mealybug species associated with dragon fruits in Indonesia, namely Ferrisia virgata, Phenacoccus solenopsis, Planococcus minor and Pseudococcus jackbeardsleyi, can now be identified using the identification key provided. 


\section{ACKNOWLEDGEMENTS}

We gratefully acknowledge Agency for Agricultural Extension and Human Resources Development, Ministry of Agriculture Republic Indonesia, to grant a scholarship to the first author. The authors also would like to convey their gratitude to Soekarno Hatta Agricultural Quarantine Office, Tangerang, Banten and Insect Biosystematics Laboratory, Department of Plant Protection, Faculty of Agriculture, IPB University who gave permission and provided facilities to conduct this research. We would also like to thank the reviewers for their valuable comments.

\section{REFERENCES}

Bahder BW, Bollinger ML, Sudarshana MR, Zalom FG. 2015. Preparation of mealybugs (Hemiptera: Pseudococcidae) for genetic characterization and morphological examination. J Insect Sci 15(1): 104. DOI: $10.1093 /$ jisesa/iev086.

[BPS] Badan Pusat Statistik. 2020. Indikator Pertanian 2019. Jakarta: Badan Pusat Statistik. www.bps.go.id/publication/download.html.

Cox JM. 1989. The mealybug genus Planococcus (Homoptera: Pseudococcidae). Bull Br Mus (Nat Hist) Entomol 58(1): 1-78.

Francis AW, Kairo MTK, Roda AL. 2012. Developmental and reproductive biology of Planococcus minor (Hemiptera: Pseudococcidae) under constant temperature. Fla Entomol 95(2): 297 303. DOI: 10.1653/024.095.0209.

Morales MG, Denno BD, Miller DR, Miller GL, Ben-Dov Y, Hardly NB. 2021. Scalenet: A literature-based model of scale insect biology and systematics. Database 2016: 1-5. DOI: 10.1093/database/bav118.

Gullan PJ. 2000. Identification of the immature instars of mealybugs (Hemiptera: Pseudococcidae) found on citrus in Australia. Australian J Entomol 39(3): 160-166. DOI: 10.1046/j.1440-6055.2000.00171.x.

Hodgson C, Abbas G, Arif MJ, Saeed S, Karar H. 2008. Phenacoccus solenopsis Tinsley (Sternorrhyncha: Coccoidea: Pseudococcidae), an invasive mealybug damaging cotton in Pakistan and India, with a discussion on seasonal morphological variation. Zootaxa 1913: 1-35 DOI: 10.11646/zootaxa.1913.1.1

Ibrahim SS, Moharum FA, El-Ghany NMA. 2015. The cotton mealybug Phenacoccus solenopsis Tinsley (Hemiptera: Pseudococcidae) as a new insect pest on tomato plants in Egypt. J Plant Prot Res 55(1): 4851. DOI: $10.1515 /$ jppr-2015-0007.

[ICAC] International Cotton Advisory Committee. 2011. Technical highlights: $5^{\text {th }}$ meeting of the Asian cotton research and development network. ICAC Rec 24(2): 3-18.

Kaydan MB, Gullan PJ. 2012. A taxonomic revision of the mealybug genus Ferrisia Fullaway (Hemiptera: Pseudococcidae), with description of eight new species and a new genus. Zootaxa 3543: 165. DOI: 10.11646/zootaxa.3543.1.1.

Krantz GW, Walter DE. 2009. A Manual Acarology, Third Edition. Texas Tech University Press, Texas.

Mani M, Shivaraju C. 2014. Mealybugs and Their Management in Agricultural and Horticultural Crops. Springer (India) Pvt Ltd, London.

Miller DA, Rung A, Parikh G. 2014. Scale Insects, edition 2, a tool for the identification of potential pest scales at USA ports-of-entry (Hemiptera: Sternorrhyncha: Coccoidea). ZooKeys 431: 61-78. DOI: 10.3897/zookeys.431.7474.

Muniappan R, Shepard BM, Watson GW, Carner GR, Rauf A, Sartiami D, Hidayat P, Afun JVK, Goergen G, Rahman AKMZ. 2011. New records of invasive insects (Hemiptera: Sternorrhynca) in Southeast
Asia and West Africa. J Agric Urban Entomol 26(4): 167-174. DOI: 10.3954/1523-5475-26.4.167.

Nurhafizhah AY, Widians JA, Budiman E. 2020. Dragon fruit pest identification expert system. Jurti 4(1): 11-18.

Oliveira MD, Barbosa PRR, Silva-Torres CSA, Torres JB. 2013. Performance of the striped mealybug Ferrisia virgata Cockerell (Hemiptera: Pseudococcidae) under variable conditions of temperature and mating. Neotrop Entomol 43(1): 1-8. DOI: 10.1007/s13744-013-0171-z.

Oliveira MD, Silva-Torres CSA, Torres JB, Oliveira JEM. 2014. Population growth and within-plant distribution of the striped mealybug Ferrisia virgata (Cockerell) (Hemiptera: Pseudococcidae) on cotton. Rev Brasileira de Entomol 58(1): 71-76. DOI: 10.1590/S0085-56262014000100012.

Pacheco da Silva VC, Bertin A, Blin A, Germain JF, Bernardi D, Rignol G, Botton M, Malausa T. 2014. Molecular and morphological identification of mealybug species (Hemiptera: Pseudococcidae) in Brazilian vineyards. PLoS ONE 9(7): e103267. DOI: 10.1371/journal.pone.0103267.

Piyaphongkul J, Suraksakul P, Tangchitsomkid N, Sahaya S. 2018. Thermal acclimation capacity of Jack Beardsley mealybug (Pseudococcus jackbeardsleyi) to survive in a warming world. J AsiaPasific Entomol 21: 737-742. DOI: 10.1016/j.aspen.2018.05.003.

Prasad YG, Prabhakar M, Sreedevi G, Ramachandra R, Venkateswarlu B. 2012. Effect of temperature on development, survival and reproduction of the mealybug, Phenacoccus solenopsis Tinsley (Hemiptera: Pseudococcidae) on cotton. Crop Protection 39: 81-88. DOI: 10.1016/j.cropro.2012.03.027.

Sartiami D, Saptayanti N, Syahputra E, Mardiasih WP, Desmawati. 2019. Mealybugs (Hemiptera: Pseudococcidae) associated with dragon fruit in Indonesia. Adv Biol Sci Res 8: 29-34. DOI: 10.2991/absr.k.200513.005.

Sartiami D, Watson GW, Roff MMN, Idris AB. 2016a. Mealybugs (Hemiptera: Coccomorpha: Pseudococcidae) attacking Hibiscus rosasinensis L. in Malaysia, with two new country records. AIP Conf Proc 1784: 06007-1-06007-7. DOI: 10.1063/1.4966845.

Sartiami D, Watson GW, Roff MMN, Idris AB. 2016b. New Indonesian records and species information for mealybugs (Hemiptera: Pseudococcidae) in Wirjati's collection. Redia 99: 155-161. DOI: 10.19263/REDIA-99.16.20.

Sirisena UGAI, Watson GW, Hemachandra KS, Wijayagunasekara HNP. 2013. A modified technique for the preparation of specimens of Sternorrhyncha for taxonomic studies. Trop Agric Res 24(2): 139149.

Wakgari WM, Giliomee JH. 2005. Description of adult and immature females of six mealybug species (Hemiptera: Pseudococcidae) found on citrus in South Africa. Afr Entomol 13(1): 281-332.

Walker AK, Crosby TK. 1988. The Preparation and Curation of Insect. DSIR, Wellington.

Wang YS, Zhou P, Tian H, Wan FH, Zhang GF. 2018. First record of the invasive pest Pseudococcus jackbeardsleyi (Hemiptera: Pseudococcidae) on the Chinese Mainland and its rapid identification based on species-specific Polymerase Chain Reaction. J of Econ Entomol 20(10): 1-9. DOI: 10.1093/jee/toy223.

Watson GW, Chandler LR. 2000. Identification of Mealybugs Important In the Caribbean Region. Second edition (revised). Egham, Surrey.

Williams DJ. 2004. Mealybugs of Southern Asia. The Natural History Museum, London.

Williams DJ, Granara de Willink MC. 1992. Mealybugs of Central and South America. CAB International, Wallingford.

Wilson LJ, Whitehouse MEA, Herron GA. 2018. The management of insect pest in Australian cotton: An evolving story. Annu Rev of Entomol 63(1): 215-37. DOI: 10.1146/annurev-ento-020117-043432.

Zarkani A, Apriyanto D, Turanli F, Kaydan MB. 2020. New record of Ferrisia dasylirii (Cockerell) (Hemiptera: Cocomorpha: Pseudococcidae) in Indonesia. Serangga 25(3): 93-100. 